\title{
Dietary supplementation of Saanen goats with dried licorice root modifies chemical and textural properties of dairy products
}

\author{
Francesca Bennato, ${ }^{1}$ Andrea lanni, ${ }^{2}$ ๑ Camillo Martino, ${ }^{3}$ Alessio Di Luca, ${ }^{1} \odot$ Denise Innosa, ${ }^{1}$ \\ Armando Marco Fusco, ${ }^{1}$ Francesco Pomilio, ${ }^{4}$ and Giuseppe Martino ${ }^{1 *}$ (i) \\ ${ }^{1}$ Faculty of BioScience and Technology for Food, Agriculture and Environment, University of Teramo, Italy 64100 \\ ${ }^{2}$ Department of Medical, Oral and Biotechnological Sciences, "G. d'Annunzio" University Chieti-Pescara, 66100 Chieti, Italy \\ ${ }^{3}$ Specialist Diagnostic Department, Istituto Zooprofilattico Sperimentale dell'Abruzzo e del Molise "G. Caporale," 64100 Teramo, Italy \\ ${ }^{4}$ Food Hygiene Unit, NRL for L. monocytogenes, Istituto Zooprofilattico Sperimentale dell'Abruzzo e del Molise "G. Caporale," 64100 Teramo, Italy
}

\begin{abstract}
The aim of the present study was to evaluate the effect of dietary integration with dried licorice root on the chemical-nutritional qualities of goat milk and cheeses. The study was conducted for $60 \mathrm{~d}$, during which 30 Saanen goats were divided into 2 groups: a control group (CG) that received a standard diet and an experimental group (LG+) whose diet was supplemented with licorice. At the end of the study, milk samples were collected to determine chemicalnutritional compositions and fatty acid (FA) profiles. Cheeses produced with CG and LG+ bulk milk were analyzed for chemical-physical parameters after 3 (T3) and 30 (T30) d of ripening. A different FA profile and a significant increase in protein and casein were observed in LG+ milk samples compared with CG milk. Regarding cheeses, an increase of proteins and fat was found in LG+ cheeses, which also were harder, more elastic, and more gummy than the CG samples after both 3 and $30 \mathrm{~d}$ of ripening. A different protein profile was detected in the 2 groups without significant variations in casein fractions $\left(\alpha_{S 2^{-}}\right.$casein and $\beta$-casein) during ripening. Moreover, greater oxidative stability was found in LG+ cheeses at both T3 and T30. Different families of volatile compounds were detected in T30 cheeses obtained from both groups. A significant reduction of octanoic acid and an increase in nonanal and ketones were found in LG+ T3 cheeses, whereas the LG+ T30 cheeses were characterized by a significant decrease of hexanoic acid an increase of 3-methyl-1-butanol and acetoin. We concluded that it is possible to assert that dietary integration with dried licorice root modified chemical and technological properties of goat cheeses, reducing lipid oxidation during ripening and inducing
\end{abstract}

Received April 20, 2019.

Accepted September 15, 2019.

*Corresponding author: gmartino@unite.it changes in texture that could improve consumer acceptability, although further studies are needed from this point of view.

Key words: licorice root, dairy goat, volatile compound, proteolysis

\section{INTRODUCTION}

Interest in goat milk is increasing, due to its recognized nutritional properties compared with cow milk (Raynal-Ljutovac et al., 2008; Silanikove et al., 2010). In fact, compared with cow milk, goat milk is characterized by smaller fat globule size and greater content of proteins of high biological value, essential fatty acids (FA), minerals, and vitamins (Haenlein, 2004; Park and Haenlein, 2007). Goat milk FA profile consists of a larger content of medium-chain FA such as caproic (C6:0), caprylic (C8:0), and capric (C10:0) acids, which represent up to 15 to $18 \%$ of total FA in goat milk and, due to their great energy-giving facility, play a key role in human nutrition (Haenlein, 1992; Park, 1992; Sanz Sampelayo et al., 2007).

Chemical-nutritional composition and renneting properties of milk are influenced by several factors, including animal species, breed, genotype, stage of lactation, and diet (Morand-Fehr et al., 2007). These factors can affect milk quality and influence its processability for cheesemaking. During cheese ripening, protein and fat undergo biochemical processes that contribute to their degradation (McSweeney and Sousa, 2000). Proteolysis is responsible for the development of flavor determinants, such as amino acids and peptides, and moreover induces changes in texture and water binding capacity as a result of the newly formed amino and carboxyl groups (Sousa et al., 2001). Lipolysis is due to the presence of lipolytic enzymes that cleave the ester bonds between fatty acids and glycerol in triacylglycerol. Such a mechanism produces free fatty acids (FFA) with chain lengths $\geq \mathrm{C} 4$, glycerol, and mono- and diacylglycerols. Free fatty acids, especially 
short-chain FFA, have been considered responsible for the characteristic aroma of goat cheeses (Salles et al., 2002; Chilliard et al., 2003).

One of the best strategies to improve the chemicalnutritional properties of milk and dairy products is to act on the animals' diet (Ianni et al., 2019a). Several studies have shown that diet supplementation with plants rich in bioactive compounds can positively influence animals' health, growth, and productivity (Waghorn and McNabb, 2003; Durmic and Blache, 2012). Licorice grows easily in Italy, mainly in the southern regions (Sicily, Calabria, and Abruzzo), and it is one of the most widely investigated and economically important medicinal plants. Fresh licorice root is composed of approximately $20 \%$ moisture, $6 \%$ ash, $30 \%$ starch, $8 \%$ protein, $1.35 \%$ fat, 15 to $20 \%$ sugars, and high contents of magnesium, calcium, potassium, sodium, zinc, manganese, iron, and copper. Licorice root has a relevant amount of phenols (0.3 to $0.5 \%$ ), flavonoids (0.1 to $0.2 \%)$, triterpene saponins, coumarins, chalcones, and isoflavones; it also contains substances with antioxidant activity (tannins, carotenoids, and ascorbic acid) and other compounds such as asparagine, glucose, fructose, FA (C2 to C16), lactones, sterols, and polysaccharides (Hayashi et al., 1998). The most important and abundant secondary metabolite present in the root is glycyrrhizin, a saponinic glucoside formed by the union of a lipophilic portion, glycyrrhetinic acid, with a hydrophilic chain constituting different molecules of sugars. The licorice effects have been evaluated in vitro, and antimicrobial (Fukai et al., 2002), antiatherosclerotic (Fuhrman et al., 2002), antioxidative (Vaya et al., 1997), anti-inflammatory (Yokota et al., 1998), estrogen-like (Somjen et al., 2004), antiviral (Fiore et al., 2008), and radical-scavenging activities (Fukai et al., 2003) have been reported. Its effects on farm animals and dairy products have not yet been well documented.

Because of high consumer demand for foods that are healthier and obtained via sustainable farming systems, a feeding strategy based on licorice root supplementation in ruminants seems promising. Therefore, the aim of this study was to investigate dietary licorice root supplementation on the chemical-nutritional and technological properties of goat dairy products.

\section{MATERIALS AND METHODS}

\section{Experimental Design, Diets, Cheesemaking, and Sampling}

The experimental plan was performed according to Directive 2010/63/EU of the European Parliament (European Union, 2010) and Directive 86/609/EEC (European Economic Community, 1986), which deal with the protection of animals used for scientific purposes.

For the study, we used 30 Saanen goats, homogeneous for age $(45 \pm 3 \mathrm{mo})$, weight $(58.5 \pm 3.5 \mathrm{~kg})$, and lactation days ( $80 \pm 5$ DIM). Animals were divided into 2 groups of 15 goats each: a control group (CG) and an experimental group $(\mathbf{L G}+)$ whose diet was supplemented with dried licorice root (DLR). The study was conducted for $60 \mathrm{~d}$, during which time goats were housed in 2 separate areas of free housing with bunks on straw, drinking troughs, and access to identical feeding areas. In this period, each group received TMR whose composition is reported in Table 1. Twice daily, in the morning $(0800 \mathrm{~h})$ and in the evening $(1800 \mathrm{~h})$, animals were administered a custom-formulated concentrate (Table 1) for a total of $1 \mathrm{~kg} /$ head per day. The concentrate of the experimental group was supplemented with DLR (10 g/head per day). Samples were analyzed for DM (method 930.15), CP (method 954.01), ether extract (method 920.39), crude fiber (method 962.09), and ash (method 942.05) according to AOAC methods (AOAC International, 1990). Neutral detergent fiber and ADF were determined by the detergent procedures of Van Soest et al. (1991).

On d 30 and d 60 of the trial, individual and bulk milk samples were collected and partly immediately analyzed for composition and partly stored at $-20^{\circ} \mathrm{C}$ for further analysis. At the end of the trial, for each group, 3 different cheesemakings were performed on 3 consecutive days (d 60, 61, and 62 from the start of the experiment). Approximately $40 \mathrm{~L}$ of milk were collected daily from each group of goats, which yielded 6 cheeses/d per group, of about $650( \pm 35) \mathrm{g}$ each; therefore, for each treatment, a total of 18 cheeses were produced ( 6 cheeses $\times 3$ cheesemakings).

The cheese was produced following the manufacturing protocol reported below. Bulk milk was pasteurized at $72^{\circ} \mathrm{C}$ for $20 \mathrm{~s}$, cooled to $36 \pm 1^{\circ} \mathrm{C}$, and transferred to a container in which mesophilic or thermophilic starter bacteria (500 U/5,000 L) were added, followed by acidification. Rennet (75\% chymosin and $25 \%$ pepsin; 1:18,000 strength; Clerici, Cadorago, Italy) was added $(15 \mathrm{~g} / 100 \mathrm{~kg})$, and coagulation began after $30 \mathrm{~min}$ of incubation. The curd was broken into small pieces approximately the size of hazelnuts, portioned in aliquots of about $1 \mathrm{~kg}$, transferred into plastic molds, and kept at $48 \pm 1.5^{\circ} \mathrm{C}$ until the $\mathrm{pH}$ reached $5.20 \pm 0.1$. Then, a $20 \% \mathrm{NaCl}$ water solution was used to salt the cheese in brine. Thereafter, the salted fresh cheese was stored in the ripening room at a controlled temperature of $10^{\circ} \mathrm{C} \pm 0.5$ and a relative humidity of $85 \%$. To evaluate changes in chemical composition and quality attributes due to ripening, one half of the cheeses (9 per group) were sampled after $3 \mathrm{~d}$ of storage (T3), and the other 
half was analyzed after $30 \mathrm{~d}$ of ripening (T30). Samples of cheese were partly immediately analyzed and partly vacuum-packed and frozen at $-20^{\circ} \mathrm{C}$ until analysis.

\section{HPLC Determination of Glycyrrhizic Acid}

The glycyrrhizic acid content of licorice root was evaluated after previous extraction with a methanol: water $(1: 1, \mathrm{vol} / \mathrm{vol})$ solution. The separation of analytes was carried out using an HPLC chromatographic system (Varian, Harbor City, CA) equipped with a Supelcosil LC-18 HPLC column $(25 \mathrm{~cm} \times 4.6 \mathrm{~mm}, 5$ $\mu \mathrm{m}$; Sigma-Aldrich, Milan, Italy). Isocratic conditions with a mobile phase containing $65 \%$ methanol, $30 \%$ water, and $5 \%$ acetic acid were used. The flow rate of the mobile phase was $1 \mathrm{~mL} / \mathrm{min}$, and the column temperature was set at $40 \pm 0.1^{\circ} \mathrm{C}$. The peaks were detected at $258 \mathrm{~nm}$. Glycyrrhizic acid ammonium salt (Fluka BioChemika, Switzerland) was used as the standard to obtain a calibration curve that was linear in the

Table 1. Ingredient and chemical composition of TMR and customformulated concentrate administered to Saanen goats fed a standard diet $(\mathrm{CG})$ or a custom-formulated dietary supplement containing licorice root $(\mathrm{LG}+)$

\begin{tabular}{|c|c|c|}
\hline Item & \multicolumn{2}{|c|}{ Value } \\
\hline \multicolumn{3}{|l|}{ TMR } \\
\hline \multicolumn{3}{|l|}{ Ingredient, \% DM } \\
\hline Alfalfa hay & \multicolumn{2}{|c|}{38.0} \\
\hline Mixed grass hay & \multicolumn{2}{|c|}{25.0} \\
\hline Soybean meal & \multicolumn{2}{|c|}{13.0} \\
\hline Corn grain meal & \multicolumn{2}{|c|}{12.0} \\
\hline Barley meal & \multicolumn{2}{|c|}{5.0} \\
\hline Beet pulp, dried & \multicolumn{2}{|c|}{4.0} \\
\hline Mineral and vitamin supplement & \multicolumn{2}{|c|}{3.0} \\
\hline \multicolumn{3}{|l|}{ Chemical composition } \\
\hline $\mathrm{DM}, \%$ & \multicolumn{2}{|c|}{87.5} \\
\hline $\mathrm{CP}, 1 \%$ & \multicolumn{2}{|c|}{16.9} \\
\hline Ash. ${ }^{1} \%$ & \multicolumn{2}{|c|}{8.5} \\
\hline Ether extract, ${ }^{1} \%$ & \multicolumn{2}{|c|}{2.7} \\
\hline $\mathrm{NDF},{ }^{1} \%$ & & \\
\hline $\mathrm{ADF}, 1 \%$ & \multicolumn{2}{|c|}{24.3} \\
\hline Custom-formulated concentrate & CG & $\mathrm{LG}+$ \\
\hline \multicolumn{3}{|l|}{ Ingredient, $\%$ as fed } \\
\hline Barley meal & 78.0 & 77.5 \\
\hline Soybean meal & 19.0 & 18.5 \\
\hline Mineral and vitamin supplement & 3.0 & 3.0 \\
\hline Licorice root & - & 1.0 \\
\hline \multicolumn{3}{|l|}{ Chemical composition } \\
\hline DM, \% & 86.4 & 86.4 \\
\hline $\mathrm{CP}^{1} \%$ & 15.3 & 14.9 \\
\hline$A \operatorname{sh}^{1} \%$ & 5.2 & 5.2 \\
\hline Ether extract. ${ }^{1} \%$ & 3.6 & 3.6 \\
\hline $\mathrm{NDF},{ }^{1} \%$ & 9.6 & 10.0 \\
\hline ADF. $1 \%$ & 4.2 & 4.3 \\
\hline
\end{tabular}

${ }^{1}$ On a DM basis. range of concentration 50 to $250 \mu \mathrm{g} / \mathrm{mL}\left(\mathrm{R}^{2}=0.996\right)$. The calculated lines of regression have been used to compute the amount of glycyrrhizic acid.

\section{Chemical Composition of Milk and Cheese}

The chemical composition of milk (fat, protein, casein, lactose, and urea) was determined using a MilkoScan FT 6000 (Foss Integrator IMT; Foss Analytics, Hillerød, Denmark), and SCC was performed using a Fossomatic TM FC (Foss Analytics). Evaluations were carried out on individual milk samples collected before every cheesemaking, for a total of 45 observations for each group (15 observations $\times 3$ samplings).

For cheese, DM and total protein contents were determined according to AOAC methods (AOAC International, 2000). Lipid extraction was carried out via acid hydrolysis. Samples of $2.5 \mathrm{~g}$ were homogenized in $20 \mathrm{~mL}$ of ethanol with $500 \mu \mathrm{L}$ of $3 N$ hydrochloric acid. The amount of fat and protein was expressed as percentage of DM.

\section{Fatty Acid Profiles of Milk and Cheese}

The milk lipid fraction was extracted according to the AOAC official method (AOAC International, 1990), and in cheese the extraction was performed using a mix of chloroform and methanol $(2: 1, \mathrm{vol} / \mathrm{vol})$. The extracted fat was analyzed for FA composition. For both milk and cheese, $50 \mathrm{mg}$ of lipids were reconstituted, with $1 \mathrm{~mL}$ of hexane containing C21:0 methyl ester as internal standard (Sigma-Aldrich), and methylation was performed by the addition of $500 \mu \mathrm{L}$ of sodium methoxide in methanol $(1: 1, \mathrm{vol} / \mathrm{vol})$. Detection of fatty acid methyl esters was performed via gas chromatograph (Focus GC; Thermo Fisher Scientific, Waltham, MA) equipped with a capillary column (Restek Rt-2560 Column, fused silica $100 \mathrm{~m} \times 0.25 \mathrm{~mm}$ highly polar phase; Restek Corporation, Bellefonte, PA) and a flame ionization detector. Hydrogen was used as carrier gas. The initial holding temperature was $80^{\circ} \mathrm{C}$ for $10 \mathrm{~min}$; then it was increased to $172^{\circ} \mathrm{C}$ at a rate of $4^{\circ} \mathrm{C} / \mathrm{min}$ and held for $10 \mathrm{~min}$. The final temperature of $190^{\circ} \mathrm{C}$ was reached at a rate of $4^{\circ} \mathrm{C} / \mathrm{min}$ and held for $10 \mathrm{~min}$. The identification of individual fatty acid methyl esters was performed by comparing the retention time of a standard mixture (FIM-FAME7-Mix; Matreya LLC, Pleasant Gap, PA) with those of individual C18:1 trans-11 and C18:2 cis-9,trans-11 (Matreya LLC). Peak areas were quantified using ChromeCard software (Thermo Fisher Scientific), and the relative value of each individual FA was expressed as a percentage of the total FA. 


\section{Cheese Protein Extraction and SDS-PAGE}

Protein degradation in cheeses was evaluated via SDS-PAGE, using the procedure reported by Laemmli (1970). For protein extraction, $1 \mathrm{~g}$ of cheese sample was dissolved in $20 \mathrm{~mL}$ of Tris-glycine $0.01 \mathrm{M}, \mathrm{pH} 8.3$, and urea $6 \mathrm{M}$ and homogenized for $2 \mathrm{~min}$. The extract was incubated for $2 \mathrm{~h}$ at $37^{\circ} \mathrm{C}$ to facilitate casein solubilization. The solution was centrifuged at $10,000 \times g\left(4^{\circ} \mathrm{C}\right)$ for $15 \mathrm{~min}$, and the supernatant was recovered and filtered through Whatman filter paper to remove fat and other insoluble solids. The extracted proteins were then quantified using the Bradford method (Bradford, 1976) with BSA as standard. Protein extracts were mixed with equal volume of sample buffer $[0.5 M$ Tris- $\mathrm{HCl}, \mathrm{pH} 6.8$; $2 \%$ (wt/vol) SDS; $7 \%$ (vol/vol) glycerol; $4.3 \%$ (vol/vol) $\beta$-mercaptoethanol; $0.0025 \%$ (wt/vol) bromophenol blue]. The mixture was boiled for $5 \mathrm{~min}$ to inactivate enzymes and denaturate proteins. Protein samples (10 $\mu \mathrm{g})$ were loaded onto a $15 \%$ SDS-PAGE for separation. Gels were stained with $0.5 \%$ (wt/vol) Coomassie Blue R-250, dissolved in 50\% (vol/vol) methanol and 10\% acetic acid for $45 \mathrm{~min}$ and destained with $10 \%$ acetic acid and 50\% (vol/vol) methanol. Molecular weights of the polypeptides were estimated using a molecular weight calibration kit (Precision Plus Protein All Blue Standards, Bio-Rad, Segrate, Italy), and SDS-PAGE was performed in triplicate. Densitometric analysis of the bands was performed using ImageJ software (Rasband, 2012), and the content of caseins and lowmolecular-weight products (LMWP) was expressed as a percentage of the total protein content.

\section{Evaluation of Lipid Oxidation in Cheese by Thiobarbituric Acid Reactive Substance Test}

Lipid oxidation in cheeses was evaluated by measuring thiobarbituric acid reactive substances (TBARS). Analysis was performed according to the procedure reported by Grotta et al. (2017). For each sample, an aliquot of $2.5 \mathrm{~g}$ of cheese was mixed with $500 \mu \mathrm{L}$ of $0.1 \%$ butylated hydroxytoluene in methanol, to stop the oxidation process. The mixture was homogenized in $20 \mathrm{~mL}$ of an aqueous solution of $7.5 \%$ trichloroacetic acid and then subjected to distillation. An aliquot of $5 \mathrm{~mL}$ of each distillate was mixed with an equal volume of a $0.02 M$ thiobarbituric acid (TBA) solution in $90 \%$ acetic acid. The solution was kept for $45 \mathrm{~min}$ in a thermostated bath at $95^{\circ} \mathrm{C}$, and after cooling, the absorbance at $534 \mathrm{~nm}$ was evaluated with a spectrophotometer (Jenway, Wickford, UK). The amount of malondialdehyde of each sample was calculated using a calibration curve, and results were expressed in micrograms of malondialdehyde per kilogram of DM.

\section{Volatile Compounds Analysis}

Extraction of volatile compounds from cheese samples was performed via solid-phase microextraction, and GC-MS analysis was performed with a gas chromatograph (Clarus 580; Perkin Elmer, Waltham, MA) coupled with a mass spectrometer (SQ8S; Perkin Elmer). The GC was equipped with an Elite-5MS column (length $\times$ internal diameter: $30 \times 0.25 ; 92 \mathrm{~mm}$; film thickness: $0.25 \mu \mathrm{m}$; Perkin Elmer). Five grams of cheese, previously grated, was mixed with $10 \mathrm{~mL}$ of saturated sodium chloride solution (360 g/L), and then $10 \mu \mathrm{L}$ of internal standard solution (4-methyl2-heptanone; $10 \mathrm{mg} / \mathrm{kg}$ in ethanol) was added. The vials were sealed with a polytetrafluoroethylene-silicone septum (Supelco, Bellefonte, PA) and stirred at $60^{\circ} \mathrm{C}$; volatile compounds were extracted from the headspace with a divinylbenzene-carboxen-polydimethylsiloxane solid-phase microextraction fiber (length: $1 \mathrm{~cm}$; film thickness: 50/30 $\mu \mathrm{m}$; Supelco) with an exposition time of $60 \mathrm{~min}$. After adsorption time, the extracted volatile organic compounds were thermally desorbed into the gas chromatograph injector splitless mode for $1 \mathrm{~min}$ at $250^{\circ} \mathrm{C}$. The oven temperature was held at $50^{\circ} \mathrm{C}$ for $1 \mathrm{~min}$, increased at a rate of $3^{\circ} \mathrm{C} / \mathrm{min}$ up to $200^{\circ} \mathrm{C}$ and held for $1 \mathrm{~min}$, and then increased from $200^{\circ} \mathrm{C}$ to $250^{\circ} \mathrm{C}$ at $15^{\circ} \mathrm{C} / \mathrm{min}$ and held for 15 min. Helium was used as a carrier gas at a flow rate of $1 \mathrm{~mL} / \mathrm{min}$. The mass spectrometer operated in electron impact ionization mode at $70 \mathrm{eV}$, and data were collected in full scan mode, with a scan time of $0.2 \mathrm{~s}$ over a mass range of 35 to 350 . Source and interface temperature were held at $250^{\circ} \mathrm{C}$. Volatile compounds were identified by comparison with mass spectra of a library database (NIST Mass Spectral library, Search Program version 2.0, National Institute of Standards and Technology, US Department of Commerce, Gaithersburg, MD) and by comparing the eluting order with Kovats indices.

\section{Texture Profile Analysis}

Evaluation of mechanical properties of cheese was performed using the dynamometer Instron UTM 5542 (Instron, Wycombe, UK) equipped with a flat probe of 3 -cm diameter, which allows reproduction of the conditions applied during mastication through a doublecyclic compression test (Texture Profile Analysis, TPA; Bourne, 1968). The experimental parameters adopted were as follows: pre-load $=0.05 \mathrm{~N}$; test speed $=30$ $\mathrm{mm} / \mathrm{min}$; deformation $=30 \%$. For each cheese sample, a minimum of 20 parallelepiped-shaped aliquots (1.5 $\times 1 \times 1 \mathrm{~cm}$ ) were prepared, equilibrated at $20^{\circ} \mathrm{C}$, and analyzed. The parameters determined from the force- 
deformation graph were hardness, cohesiveness, and gumminess.

\section{Statistical Analysis}

All experiments were performed in triplicate, and the results were reported as mean \pm standard deviation (SD). The SigmaPlot 12.0 software (Systat Software, Inc., San Jose, CA) for Windows operating system was used to analyze the statistical significance of the differences between the averages for each group. For chemical parameters and FA profile of milk, the means and SD were calculated and compared using $t$-test. The remaining parameters, evaluated on cheese obtained at the end of the trial, were analyzed using 1-way ANOVA, and means were compared through Tukey's test. With regard to volatile compounds and FA profile in cheese, the diet was included as fixed effect in the statistical model, and the analysis was performed independently for 3- and 30-d ripened cheeses; the 2 data sets were processed separately, and the ripening effect was not tested. A $P$-value lower than 0.05 was considered statistically significant.

\section{RESULTS}

\section{Milk and Cheese Chemical Composition}

In milk, as reported in Table 2, dietary DLR integration resulted in a significant increase in casein $(3.06 \pm$ $0.33 \%$ vs. $2.36 \pm 0.40 \% ; P<0.01)$ and protein $(4.22$ $\pm 0.41 \%$ vs. $3.39 \pm 0.46 \% ; P<0.01)$. The $\mathrm{SCC}$ was lower $(P<0.05)$ in $\mathrm{LG}+$ compared with the CG. No significant variations in urea, lactose, or fat content were observed between the 2 groups.

Chemical composition of cheeses was affected by diet; in fact, protein and fat percentages increased in LG+ samples (Table 3). Moisture content was lower $(P<$ $0.05)$ in the $\mathrm{T} 3 \mathrm{LG}+$ cheese compared with the $\mathrm{CG}$ cheese and, as expected, decreased significantly after 30 $\mathrm{d}$ of ripening in $\mathrm{CG}$ but not in $\mathrm{LG}+$ samples.

\section{Fatty Acid Profile and Lipid Oxidation in Cheese}

Dietary integration with DLR modified the FA profile (Table 4) of milk, with a significant increase of saturated FA $(76.47 \pm 0.01 \%$ vs. $71.79 \pm 0.81 \%$; $P<$ $0.001)$ and a significant reduction of MUFA (15.93 \pm $0.66 \%$ vs. $19.70 \pm 0.64 \% ; P<0.001)$ and PUFA $(2.76$ $\pm 0.11 \%$ vs. $3.35 \pm 0.27 \% ; P<0.001)$. Furthermore, we observed an increase of MUFA (38.44 $\pm 1.19 \%$ vs. $34.33 \pm 0.89 \% ; P<0.001)$ and a decrease of long-chain FA $(53.59 \pm 1.18 \%$ vs. $57.66 \pm 1.10 \% ; P<0.01)$. The major changes concerned the increase of caprylic (C8:0;
$P<0.01)$, capric $(\mathrm{C} 10: 0 ; P<0.001)$, lauric $(\mathrm{C} 12: 0 ; P$ $<0.001)$, myristic (C14:0; $P<0.05)$, palmitic (C16:0; $P<0.001)$, and palmitoleic acids (C16:1; $P<0.01$ ), and a reduction of margaric $(\mathrm{C} 17: 0 ; P<0.001)$, stearic (C18:0; $P<0.001)$, arachidic $(\mathrm{C} 20: 0 ; P<0.01)$, behenic (C22:0; $P<0.01)$, oleic (C18:1 cis-9; $P<0.001)$, linoleic (C18:2; $P<0.001)$, and linolenic acids (C18:3; $P<0.001)$.

As observed in milk, the FA profile of cheese (Table 4) was also influenced by diet, with a significant increase of saturated FA $(79.91 \pm 1.38 \%$ vs. $71.30 \pm$ $2.05 \% ; P<0.001)$ and a reduction of MUFA (13.00 \pm $1.19 \%$ vs. $19.74 \pm 1.22 \% ; P<0.001)$ and PUFA $(2.46$ $\pm 0.19 \%$ vs. $3.78 \pm 1.13 \% ; P<0.05)$. In particular, the LG+ diet resulted in a significant increase of shortchain FA $(4.16 \pm 0.65 \%$ vs. $2.86 \pm 0.76 \% ; P<0.05)$ and a decrease in medium-chain $(34.46 \pm 2.53 \%$ vs. $44.84 \pm 2.43 \% ; P<0.001)$ and long-chain FA $(57.49 \pm$ $3.10 \%$ vs. $46.67 \pm 3.04 \% ; P<0.001)$. The TBA values in fresh $\mathrm{LG}+$ cheeses were lower compared with those of CG cheeses $(0.29 \pm 0.03$ vs. $0.48 \pm 0.02 \mu \mathrm{g} / \mathrm{kg} ; P<$ $0.05)$. Lipid oxidation increased at the end of ripening (T30), but the $\mathrm{LG}+$ samples remained at lower values than did the CG samples $(0.34 \pm 0.01$ vs. $0.53 \pm 0.06$ $\mu \mathrm{g} / \mathrm{kg} ; P<0.05)$.

\section{SDS-PAGE Analysis}

The SDS-PAGE of proteins extracted from CG and $\mathrm{LG}+$ cheese samples after 3 and $30 \mathrm{~d}$ of ripening is showed in Figure 1. Under our experimental conditions, cheese proteins were separated into clear bands for $\alpha_{\mathrm{S}^{-}}$ casein $\left(\alpha_{\mathrm{S}_{2}} \mathrm{CN}\right), \beta$-casein $(\beta-\mathrm{CN})$, and several LMWP. A different protein profile was observed between the 2 groups. The $\beta-\mathrm{CN}$ bands were the most abundant in all cheese samples, even if a higher intensity was detected in LG+ cheeses compared with $\mathrm{CG}$, both at T3 $(P<$ $0.05)$ and at T30 $(P<0.001)$. However, insignificant variations were observed in $\mathrm{CG}$ and $\mathrm{LG}+$ cheeses during ripening. The $\alpha_{\mathrm{S}_{2}} \mathrm{CN}$ was more abundant in $\mathrm{LG}+$

Table 2. Chemical composition of milk obtained from the control group (CG) of Saanen goats and the experimental group (LG+) fed a custom-formulated diet supplemented with licorice root; values expressed as mean $\pm \mathrm{SD}(\mathrm{n}=45)$

\begin{tabular}{lccc}
\hline Item & CG & LG+ & $P$-value \\
\hline Casein, \% & $2.36 \pm 0.40$ & $3.06 \pm 0.33$ & $* *$ \\
Lactose, \% & $3.71 \pm 0.39$ & $4.01 \pm 0.24$ & NS \\
Fat, $\%$ & $3.01 \pm 0.49$ & $3.15 \pm 0.81$ & NS \\
Protein, \% & $3.39 \pm 0.46$ & $4.22 \pm 0.41$ & $* *$ \\
Urea, $\mathrm{mg} / 100 \mathrm{~mL}$ & $62.29 \pm 14.25$ & $59.00 \pm 3.28$ & $\mathrm{NS}$ \\
SCC,$\times 10^{3}$ cells $/ \mathrm{mL}$ & $492 \pm 42$ & $395 \pm 25$ & $*$ \\
\hline
\end{tabular}


Table 3. Chemical and nutritional composition of cheeses at 3 (T3) and 30 (T30) d of ripening, from Saanen goats fed either a standard control diet $(\mathrm{CG})$ or a custom-formulated diet supplemented with licorice root $(\mathrm{LG}+)$; values expressed as mean $\pm \mathrm{SD}$

\begin{tabular}{lrrrrr}
\hline & \multicolumn{3}{c}{$\mathrm{T} 3$} & & \multicolumn{2}{c}{ T30 } \\
\cline { 2 - 3 } \cline { 5 - 6 } Item & \multicolumn{1}{c}{$\mathrm{CG}$} & $\mathrm{LG}+$ & & $\mathrm{CG}$ & $\mathrm{LG}+$ \\
\hline Fat, \% & $36.06^{\mathrm{A}} \pm 2.57$ & $36.43^{\mathrm{A}} \pm 1.33$ & & $30.27^{\mathrm{a}, \mathrm{B}} \pm 1.83$ & $36.67^{\mathrm{b}, \mathrm{A}} \pm 2.19$ \\
Protein, \% & $47.19^{\mathrm{A}} \pm 1.12$ & $48.75^{\mathrm{A}} \pm 0.74$ & & $39.48^{\mathrm{a}, \mathrm{B}} \pm 1.30$ & $47.54^{\mathrm{b}, \mathrm{A}} \pm 1.32$ \\
DM, \% & $41.62^{\mathrm{a}, \mathrm{A}} \pm 1.76$ & $57.56^{\mathrm{b}, \mathrm{B}} \pm 1.03$ & & $48.12^{\mathrm{c}, \mathrm{C}} \pm 0.88$ & $58.90^{\mathrm{d}, \mathrm{B}} \pm 0.75$ \\
\hline
\end{tabular}

${ }^{\mathrm{a}-\mathrm{d}}$ Means with different lowercase superscript letters are significantly different by diet.

${ }^{\mathrm{A}-\mathrm{C}}$ Means with different uppercase superscript letters are significantly different by period.

samples compared with CG cheeses $(P<0.001$ for both T3 and T30), and a negative correlation between $\alpha_{\mathrm{S}^{-}}$ $\mathrm{CN}$ and LMWP was observed. In fact, a lower presence of $\alpha_{\mathrm{S}_{2}} \mathrm{CN}$ was associated with a greater presence of LMWP $(P<0.001$ for both T3 and T30).

\section{Texture in Cheese}

The results of the compression-and-relaxation test (Table 5) showed significant differences between sam- ples obtained from the 2 feeding strategies. The LG+ T3 cheeses proved harder $(10.28 \pm 3.17 \mathrm{~N}$ vs. $3.46 \pm$ $0.68 \mathrm{~N} ; P<0.001)$, more elastic $(0.68 \pm 0.04$ vs. $0.57 \pm$ $0.03 ; P<0.01)$, and more rubbery $(6.95 \pm 2.12 \mathrm{~N}$ vs. $1.99 \pm 0.43 \mathrm{~N} ; P<0.001)$ than the $\mathrm{CG}$ cheeses. The variations observed in fresh cheeses, except for elasticity, were also found in T30 cheeses; in fact, the LG+ T30 cheeses were harder $(20.68 \pm 3.92$ vs. $11.23 \pm 4.14$; $P<0.05)$ and more rubbery $(14.56 \pm 2.68$ vs. $8.30 \pm$ 2.97; $P<0.05)$ than the $\mathrm{CG}$ cheeses.

Table 4. Fatty acid composition of milk and cheese, ripened for $3 \mathrm{~d}$ (T3), obtained from Saanen goats fed either a standard control diet (CG) or a custom-formulated diet supplemented with licorice root $(\mathrm{LG}+)$; values expressed as mean $\pm \mathrm{SD}$

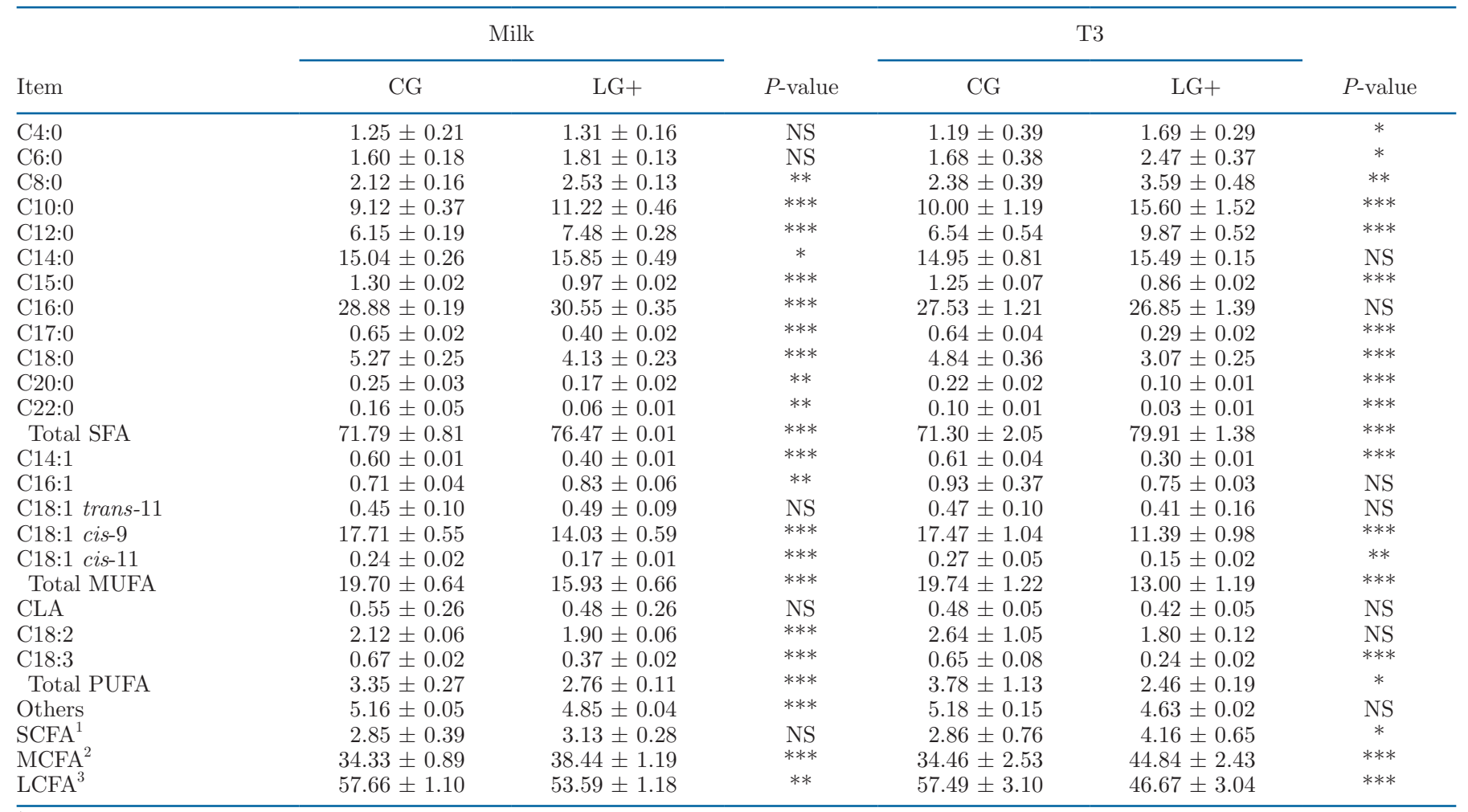

${ }^{1} \mathrm{C} 4: 0$ and $\mathrm{C} 6: 0$.

${ }^{2} \mathrm{C} 8: 0$ to $\mathrm{C} 15: 0$.

${ }^{3} \mathrm{C} 16: 0$ to $\mathrm{C} 22: 0$.

${ }^{*} P<0.05$; ** $P<0.01$; *** $P<0.001$. 
Table 5. Texture profile analysis of cheeses at 3 (T3) and 30 (T30) d of ripening, from Saanen goats fed either a standard control diet (CG) or a custom-formulated diet supplemented with licorice root (LG+); data expressed as mean $\pm \mathrm{SD}$

\begin{tabular}{|c|c|c|c|c|}
\hline \multirow[b]{2}{*}{ Item } & \multicolumn{2}{|c|}{ T3 } & \multicolumn{2}{|c|}{ T30 } \\
\hline & $\mathrm{CG}$ & $\mathrm{LG}+$ & CG & $\mathrm{LG}+$ \\
\hline Hardness, N & $3.46^{\mathrm{a}, \mathrm{A}} \pm 0.68$ & $10.28^{\mathrm{b}, \mathrm{B}} \pm 3.17$ & $11.23^{\mathrm{c}, \mathrm{B}} \pm 4.14$ & $20.68^{\mathrm{d}, \mathrm{C}} \pm 3.92$ \\
\hline Cohesiveness & $0.57^{\mathrm{a}, \mathrm{A}} \pm 0.03$ & $0.68^{\mathrm{b}, \mathrm{B}} \pm 0.04$ & $0.75^{\mathrm{C}} \pm 0.05$ & $0.71^{\mathrm{D}} \pm 0.03$ \\
\hline Gumminess, $\mathrm{N}$ & $1.99^{\mathrm{a}, \mathrm{A}} \pm 0.43$ & $6.95^{\mathrm{b}, \mathrm{B}} \pm 2.12$ & $8.30^{\mathrm{c}, \mathrm{B}} \pm 2.97$ & $14.56^{\mathrm{d}, \mathrm{C}} \pm 2.68$ \\
\hline
\end{tabular}

\section{Volatile Compounds}

In T30 cheeses, more families of volatile organic compounds were identified than in T3 samples (Table 6 ). Both at the beginning and at the end of ripening, the most abundant class of compounds was carboxylic acids, reflecting a marked lipolysis. In T3 samples, dietary DLR supplementation proved effective in inducing lower concentrations of octanoic acid (29.17 \pm $1.67 \%$ vs. $36.75 \pm 2.15 \% ; P<0.05)$, a significantly higher amount of nonanal $(5.18 \pm 0.46 \%$ vs. $0.40 \pm$ $0.06 \% ; P<0.01$ ), and a general increase in ketones (acetoin, 2-heptanone, 2-nonanone; $P<0.01$ ). Further-

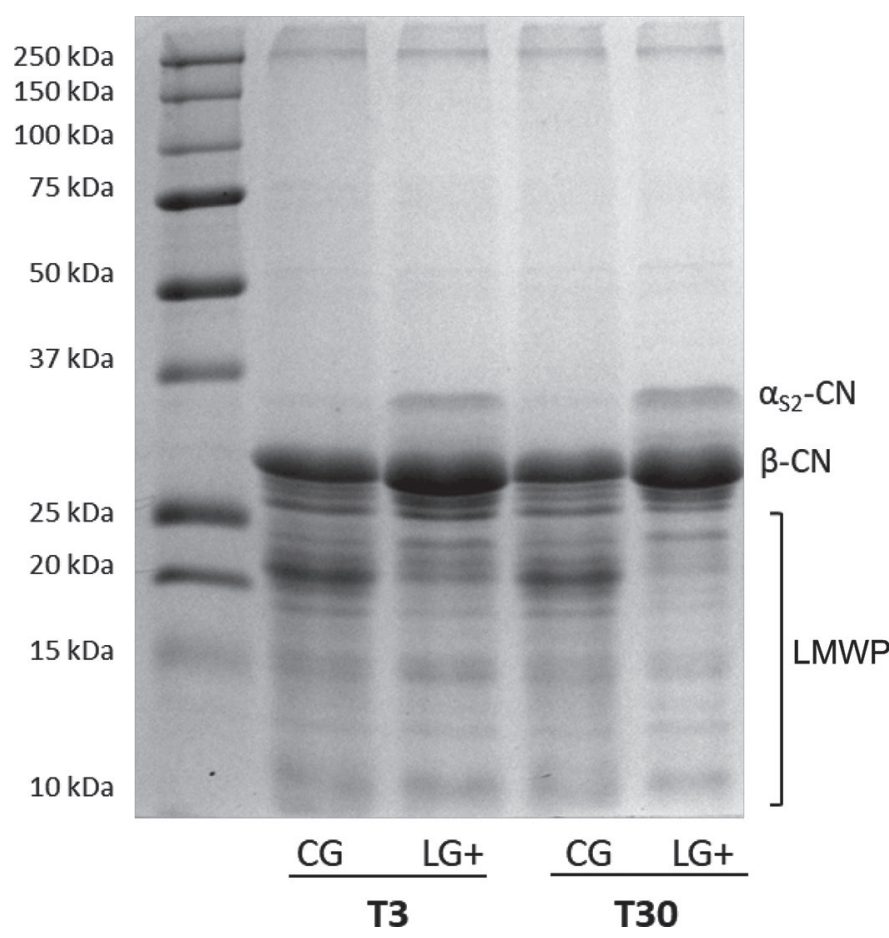

Figure 1. Results of SDS-PAGE analysis of proteins in cheeses at 3 (T3) and 30 (T30) d of ripening from Saanen goats fed either a standard control diet (CG) or a custom-formulated diet supplemented with licorice root $(\mathrm{LG}+)$. LMWP $=$ low-molecular-weight peptides. more, ripened $\mathrm{LG}+$ cheeses showed a marked reduction of hexanoic acid $(14.21 \pm 1.55 \%$ vs. $20.64 \pm 1.81 \%$; $P$ $<0.05)$ and significant increases in concentration of 3-methyl-1-butanol $(1.89 \pm 0.25 \%$ vs. $0.31 \pm 0.04 \%$; $P$ $<0.01)$ and acetoin $(1.80 \pm 0.19 \%$ vs. $0.30 \pm 0.04 \%$; $P<0.01)$.

\section{DISCUSSION}

Dietary supplementation with licorice influenced the chemical-nutritional composition of milk. A higher percentage of casein, protein, and DM, and a decrease of SSC, were found in the LG+ milk compared with the CG. It has been observed that the amounts and compositions of proteins in milk are largely determined by the genetics of the animal, but due to the high requirement of protein synthesis for energy, milk protein yield can be affected by the energy content of the diet (Reynolds et al., 1994). There are currently no studies showing how supplementation with licorice root may act on SCC; however, some research has demonstrated that feeding licorice root indirectly influences SCC by promoting the immune defense of the mammary gland and reducing incidence of infections. In addition, the anti-inflammatory activity of licorice has been already well documented (Imanishi et al., 1989; Ohtsuki et al., 1992; Nakamura et al., 1993). Our data are also supported by a study on lactating cows with mastitis caused by coagulase-negative staphylococci, in which a decrease of bacterial concentration and SCC in milk was demonstrated after intramammary infusions of glycyrrhizin (Kai et al., 2003).

Analysis of the chemical composition of cheese showed very interesting results, mainly related to the content of DM during ripening. At both T3 and T30, dietary DLR intake correlated with a higher DM percentage in cheese. However the peculiarity of the acquired data lies in the fact that, although DM increased during ripening in the CG samples, the LG+ samples showed no significant differences between T3 and T30, suggesting a higher moisture-retaining capability of these cheeses. 
The calculation of fat and protein content on a DM basis showed very marked differences in T30 cheeses; in fact, the amount of both protein and fat was higher in cheese samples obtained after dietary DLR intake. These findings are certainly the basis of the variations found in textural properties. The lower moisture in $\mathrm{LG}+$ cheese probably represents the reason why these cheeses were more hard, elastic, and rubbery than CG samples, and these differences were observed in both fresh and aged cheeses. Our data are in agreement with the results of a study in which the addition of licorice powder during cheesemaking determined changes in the physical properties of goat cheese without altering its sensory properties (Šlapkauskaite et al., 2018). In contrast, Bryant et al. (1995) reported an increase in hardness in ripened cheddar cheese in the presence of lower fat concentration, although the same authors emphasized the concept previously reported by Lawrence et al. (1987), on the basis of which it is the content and composition of caseins and the structural organization of proteins that most influence texture in cheese. Taking into account the pivotal role of proteins in the determination of nutritional and textural properties of dairy products, we investigated the protein profiles of T3 and T30 cheeses via SDS-PAGE. The SDS-PAGE has been widely used to study casein hydrolysis and the type of proteolysis in cheeses, because of its high resolution and quantitative capability. Changes in texture of cheeses are determined mainly by proteolysis rate, and the evaluation of protein breakdown products represents the major index of cheese maturation. The extent of degradation is associated with the development of the characteristic textures of most varieties of cheeses and is important to the development of flavor via the formation of peptides and AA (Fox, 1989; Sousa et al., 2001). Casein is particularly important, because it forms the structural matrix of the curd that retains fat and moisture (Lucey and Kelly, 1994), and it affects cheese yield, curd firmness, syneresis rate, moisture retention, and, ultimately, cheese quality (Lawrence et al., 1987). In our experimental conditions, the SDS-PAGE patterns of $\mathrm{LG}+$ and $\mathrm{CG}$ cheese showed absence of $\alpha_{\mathrm{S1}^{-}}$ $\mathrm{CN}$, in both T3 and T30 cheese, and a high presence of $\beta$-CN. Our data are in agreement with the literature; in fact, goat milk contains low concentrations of $\alpha_{\mathrm{S}^{-}}$ $\mathrm{CN}$, whereas $\beta-\mathrm{CN}$ is the most abundant casein in goat milk (Tziboula-Clarke, 2003). Quantitative analysis of our cheeses showed that $\beta$-CN degradation progressed slowly during ripening; high resistance of $\beta-\mathrm{CN}$ to proteolysis, as a consequence of a different proteolytic activity of non-starter cultures, is highlighted in the literature (Hayaloglu et al., 2002; Sarantinopoulos et

Table 6. Aromatic profiles of cheeses at 3 (T3) and 30 (T30) d of ripening, from Saanen goats fed either a standard control diet (CG) or a custom-formulated diet supplemented with licorice root $(\mathrm{LG}+)$; data expressed as mean $\pm \mathrm{SD}(\mathrm{n}=9)$; ND $=$ not detectable

\begin{tabular}{|c|c|c|c|c|c|c|}
\hline \multirow[b]{2}{*}{ Item } & \multicolumn{2}{|c|}{$\mathrm{T} 3$} & \multirow[b]{2}{*}{$P$-value } & \multicolumn{2}{|c|}{ T30 } & \multirow[b]{2}{*}{$P$-value } \\
\hline & $\mathrm{CG}$ & $\mathrm{LG}+$ & & $\mathrm{CG}$ & $\mathrm{LG}+$ & \\
\hline \multicolumn{7}{|l|}{ Carboxylic acid } \\
\hline Butanoic acid & ND & ND & & $2.06 \pm 0.21$ & $2.60 \pm 0.18$ & NS \\
\hline Hexanoic acid & $3.40 \pm 0.38$ & ND & & $20.64 \pm 1.81$ & $14.21 \pm 1.55$ & $*$ \\
\hline Octanoic acid & $36.75 \pm 2.15$ & $29.17 \pm 1.67$ & $*$ & $26.15 \pm 2.24$ & $24.67 \pm 2.37$ & NS \\
\hline Decanoic acid & $30.77 \pm 2.59$ & $33.46 \pm 2.97$ & NS & $20.64 \pm 1.72$ & $19.00 \pm 1.75$ & NS \\
\hline \multicolumn{7}{|l|}{ Aldehyde } \\
\hline Hexanal & $1.43 \pm 0.17$ & $2.27 \pm 0.34$ & NS & $0.47 \pm 0.05$ & $0.63 \pm 0.06$ & NS \\
\hline Nonanal & $0.40 \pm 0.06$ & $5.18 \pm 0.46$ & $* *$ & $0.50 \pm 0.07$ & $0.84 \pm 0.09$ & NS \\
\hline 3-Methyl-butanal & ND & ND & & $0.06 \pm 0.01$ & $0.08 \pm 0.01$ & NS \\
\hline \multicolumn{7}{|l|}{ Alcohols } \\
\hline 3-Methyl, 1-butanol & $6.19 \pm 0.54$ & ND & & $0.31 \pm 0.04$ & $1.89 \pm 0.25$ & $* *$ \\
\hline 2-Ethyl, 1-exanol & $8.02 \pm 1.53$ & ND & & $1.32 \pm 0.15$ & $1.67 \pm 0.17$ & NS \\
\hline 2-Nonanone & $2.36 \pm 0.37$ & $8.41 \pm 0.83$ & $* *$ & $12.37 \pm 1.47$ & $14.73 \pm 1.36$ & NS \\
\hline \multicolumn{7}{|l|}{ Lactones } \\
\hline$\delta$-Decalactone & ND & ND & & $0.20 \pm 0.03$ & $0.25 \pm 0.03$ & NS \\
\hline \multicolumn{7}{|l|}{ Esters } \\
\hline Ethyl hexanoate & ND & ND & & $0.55 \pm 0.06$ & $0.31 \pm 0.04$ & NS \\
\hline Ethyl octanoate & ND & ND & & $1.19 \pm 0.13$ & $1.87 \pm 0.17$ & NS \\
\hline Ethyl decanoate & ND & ND & & $1.23 \pm 0.13$ & $1.62 \pm 0.36$ & NS \\
\hline
\end{tabular}

${ }^{*} P<0.05 ;{ }^{* *} P<0.01$. 
al., 2002). On the other hand, the $\alpha_{\mathrm{S}_{2}} \mathrm{CN}$ bands of $\mathrm{CG}$ cheeses at 3 and $30 \mathrm{~d}$ of ripening were less discernable compared with those of the LG+ cheeses, suggesting a lesser degradation in $\mathrm{LG}+$ cheeses, which could be due to a different spatial organization of caseins in the matrix. In fact it has been demonstrated that the rate of protein degradation is strongly associated with the accessibility of proteolytic enzymes to the cheese substrates, which is governed by the structure and configuration of the cheese protein (Park, 2001).

The diet enriched with DLR induced changes in the FA profile in milk and cheese. In both cases DLR dietary supplementation induced in the $\mathrm{LG}+$ samples an increase of medium-chain FA (C8:0 to C16:0) and a decrease of long-chain FA; moreover, we observed an increase of saturated FA and a decrease of MUFA and PUFA. This result appears to be in contrast with what was previously reported by Szczechowiak et al. (2016), who investigated the effects of dietary intake of condensed tannins on the FA proportion in rumen and milk in dairy cows, finding an effective modulation of rumen biohydrogenation and fermentation as well as of the microbial population. In particular, the authors reported an increase in concentration of vaccenic acid through the inhibition of the last steps of rumen biohydrogenation, preventing reduction to stearic acid (C18:0). Szczechowiak et al. (2018), using similar experimental conditions, observed a significant increase of the proportion of vaccenic acid and n-3 FA in plasma, a predisposing condition for PUFA accumulation in the mammary gland, which leads to the secretion of PUFA in milk.

Because the FA from C6:0 to C14:0 are synthesized ex novo by the mammary gland, it is plausible to suppose a stimulatory effect of licorice on lipogenic enzymes. Fatty acids with less than 12 carbons are associated with the typical flavors of small ruminant cheeses (Salles et al., 2002). Lauric (C12:0), myristic (C14:0), and palmitic acids (C16:0) are considered potentially atherogenic if consumed in excess (Haug et al., 2007), whereas shortchain FA (acetate, propionate, and butyrate) have been pointed out as the link between diet, gut microbiota, and host energy metabolism (den Besten et al., 2013). Because palmitic acid (C16:0) derives partly from the diet and partly from ex novo synthesis, its increase in LG+ milk and cheese samples could be due to greater dietary intake. As previously reported by Yunusova et al. (1995), palmitic acid effectively prevails among the saturated acids in Glycyrrhiza glabra roots; therefore, an increase in concentration in milk is plausible with an increase in concentration in the diet. By contrast, no variations of linoleic acid (C18:2) were evidenced in this study, although the aforementioned authors have highlighted its presence in licorice root in high concentrations.

The evaluation of TBARS was used in this study as a marker for lipid oxidative damage in cheese. It has been shown that flavonoids in licorice have an antioxidant activity 100 times greater than that of vitamin $\mathrm{E}(\mathrm{Ju}$ et al., 1989). After only $3 \mathrm{~d}$ from cheesemaking, the TBA values of cheese obtained from the experimental group (LG+) were significantly lower than those of the CG cheese. At the end of ripening (T30), TBA values, as expected, increased, still remaining lower in LG+ cheese than in CG. These results may be related to a greater presence of licorice root bioactive compounds in both milk and cheese that could contribute to inhibition of the lipid oxidation reactions pathway.

Recently, some evidence has been reported on the fact that aromatic profiles of dairy products can be influenced by the diet administered to animals, in particular by using matrices rich in bioactive compounds (Bennato et al., 2019; Ianni et al., 2019b). In this study, several classes of volatile organic compounds, mostly derived from the lypolitic process, were detected in both T3 and T30 cheeses. The most represented class of compounds is that of FFA, which are reported to be involved mainly in the determination of cheese flavor. The general increase of these compounds in cheeses is frequently explained by the extent of starter cell autolysis, with the consequent release of enzymes, especially lipases, that promote lipolysis by cleaving the ester linkage between an FA and the glycerol of the triacylglycerol (Collins et al., 2003). This mechanism produces FFA, especially short-chain FFA such as butanoic and hexanoic acids, that are considered the main determinants of the characteristic aromas of goat cheeses (Salles et al., 2002; Chilliard et al., 2003). The lower concentration of hexanoic acid in LG+ samples at T30 could represent an interesting finding due to the fact that this compound is commonly responsible for strong and unpleasant odors, described as sweaty, rancid, and cheesy (Bertuzzi et al., 2018). With regard to aldehydes, the only variation was observed in T3 cheeses, with a marked increase of nonanal after dietary supplementation with DLR. This compound is generally released from nonenzymatic auto-oxidation reactions, which involve unsaturated fatty acids, both free and esterified (Alewijn, 2006); these events are not particularly frequent in cheese, but when this reaction occurs, it produces straight-chain aldehydes, which are responsible for pleasant "green grasslike" aromas (Bertuzzi et al., 2018). Among the alcohols, the only significant variation concerned 3-methyl-1-butanol, which increased as a result of the DLR intake in T30 samples. Because it is a derivative of leucine degradation, this 
compound represents an indicator of proteolysis and is reported to be responsible for alcoholic and fruity odors in Swiss-type cheese (Thierry and Maillard, 2002). With reference to the ketones, the most interesting finding concerned the acetoin increase in LG+ samples at both T3 and T30. Several mechanisms have been described for the synthesis of ketones (Bertuzzi et al., 2018); however, the specific increase in acetoin could represent an effect of licorice bioactive compounds in influencing citrate metabolism. After cheesemaking, the residual citrate present in the curd can, in fact, be metabolized by citrate-positive lactic acid bacteria in acetate and lactate, from which can originate other important aromatic compounds such as acetoin, 2,3-butanediol, diacetyl, and 2-butanone (Singh et al., 2003; McSweeney et al., 2017).

\section{CONCLUSIONS}

The present study suggest the ability of dietary licorice root supplementation to affect the nutritional and technological properties of goat dairy products. In milk, the increase in protein and casein content and the reduction of SCC suggest a positive effect of licorice in improving mammary gland functionality. Changes in milk composition also influenced chemical and technological properties of cheese. Evaluation of the volatile compound profiles in fresh and ripened cheeses showed that dietary licorice intake induced changes that could lead to improvements in cheese flavor, especially with the drastic reduction of hexanoic acid, commonly responsible for strong and unpleasant odors. Also, with regard to textural analysis, the experimental diet should have given rise to cheeses with improved properties. This aspect is of crucial importance because it is this property by which the consumer first identifies and judges the product; however, it will be necessary to verify whether these changes have any effect on consumer acceptability.

\section{REFERENCES}

Alewijn, M. 2006. Formation of fat-derived flavour compounds during the ripening of Gouda-type cheese. $\mathrm{PhD}$ thesis. Wageningen Univ., the Netherlands.

AOAC International. 1990. Official Methods of Analysis. 15th ed. AOAC International, Arlington, VA.

AOAC International. 2000. Official Methods of Analysis. 17th ed. AOAC International, Washington, DC.

Bennato, F., A. Ianni, D. Innosa, L. Grotta, A. D'Onofrio, and G. Martino. 2019. Chemical-nutritional characteristics and aromatic profile of milk and related dairy products obtained from goats fed with extruded linseed. Asian-Australas. J. Anim. Sci. https://doi .org/10.5713/ajas.18.0868. In press.

Bertuzzi, A. S., P. L. H. McSweeney, M. C. Rea, and K. N. Kilcawley. 2018. Detection of volatile compounds of cheese and their contribution to the flavor profile of surface-ripened cheese. Compr. Rev. Food Sci. Food Saf. 17:371-390.
Bourne, M. C. 1968. Texture profile of ripening pears. J. Food Sci. $33: 223-226$.

Bradford, M. M. 1976. A rapid and sensitive method for the quantitation of microgram quantities of protein utilizing the principle of protein-dye binding. Anal. Biochem. 72:248-254.

Bryant, A., Z. Ustunol, and J. Steffe. 1995. Texture of Cheddar cheese as influenced by fat reduction. J. Food Sci. 60:1216-1219.

Chilliard, Y., A. Ferlay, J. Rouel, and G. Lamberet. 2003. A review of nutritional and physiological factors affecting goat milk lipid synthesis and lipolysis. J. Dairy Sci. 86:1751-1770.

Collins, Y. F., P. L. H. McSweeney, and M. G. Wilkinson. 2003. Lipolysis and free fatty acid catabolism in cheese: A review of current knowledge. Int. Dairy J. 13:841-866.

den Besten, G., K. van Eunen, A. K. Groen, K. Venema, D. J. Reijngoud, and B. M. Bakker. 2013. The role of short-chain fatty acids in the interplay between diet, gut microbiota, and host energy metabolism. J. Lipid Res. 54:2325-2340.

Durmic, Z., and D. Blache. 2012. Bioactive plants and plant products: Effects on animal function, health and welfare. Anim. Feed Sci. Technol. 176:150-162.

European Economic Community. 1986. EEC Council Directive 86/609/EEC of 24 November 1986 on the approximation of laws, regulations and administrative provisions of the Member States regarding the protection of animals used for experimental and other scientific purposes. Off. J. L 358:1-28.

European Union. 2010. Directive 2010/63/EU of the European parliament and of the council of 22 September 2010 on the protection of animals used for scientific purposes. Accessed Apr. 3, 2015. http: //eur-lex.europa.eu/legal-content/EN/TXT/PDF/?uri=CELEX: 32010L0063\&from $=$ EN.

Fiore, C., M. Eisenhut, R. Krausse, E. Ragazzi, D. Pellati, D. Armanini, and J. Bielenberg. 2008. Antiviral effects of Glycyrrhiza species. Phytother. Res. 22:141-148.

Fox, P. I. 1989. Proteolysis during cheese manufacture and ripening. J. Dairy Sci. 72:1379-1400.

Fuhrman, B., N. Volkova, M. Kaplan, D. Presser, J. Attias, T. Hayek, and M. Aviram. 2002. Anti-atherosclerotic effects of licorice extract supplementation on hypercholesterolemic patients: Increased resistance of LDL to atherogenic modifications, reduced plasma lipid levels, and decreased systolic blood pressure. Nutrition 18:268-273.

Fukai, T., A. Marumo, K. Kaitou, T. Kanda, S. Terada, and T. Nomura. 2002. Antimicrobial activity of licorice flavonoids against methicillin-resistant Staphylococcus aureus. Fitoterapia 73:536-539.

Fukai, T., K. Satoh, T. Nomura, and H. Sakagami. 2003. Preliminary evaluation of antinephritis and radical scavenging activities of glabridin from Glycyrrhiza glabra. Fitoterapia 74:624-629.

Grotta, L., F. Castellani, F. Palazzo, M. N. Haouet, and G. Martino. 2017. Treatment optimisation and sample preparation for the evaluation of lipid oxidation in various meats through TBARs assays before analysis. Food Anal. Methods 10:1870-1880.

Haenlein, G. F. W. 1992. Role of goat meat and milk in human nutrition. Pages 575-580 in Vol. II, Part I, Proc. 5th Intl. Conf. Goat. Indian Council of Agricultural Research Publishers, New Delhi, India.

Haenlein, G. F. W. 2004. Goat milk in human nutrition. Small Rumin. Res. 51:155-163.

Haug, A., A. Hostmark, and O. Harstad. 2007. Bovine milk in human nutrition-A review. Lipids Health Dis. 6:25.

Hayaloglu, A. A., M. Guven, and P. F. Fox. 2002. Microbiological, biochemical and technological properties of Turkish White cheese, "Beyaz Peynir". Int. Dairy J. 12:635-648.

Hayashi, H., N. Hiraoka, Y. Ikeshiro, H. Yamamoto, and T. Yoshikawa. 1998. Seasonal variation of glycyrrhizin and isoliquiritigenin glycosides in the root of Glycyrrhiza glabra. Biol. Pharm. Bull. 21:987-989.

Ianni, A., G. Di Maio, P. Pittia, L. Grotta, G. Perpetuini, R. Tofalo, A. Cichelli, and G. Martino. 2019a. Chemical-nutritional quality and oxidative stability of milk and dairy products obtained from Friesian cows fed with a dietary supplementation of dried grape pomace. J. Sci. Food Agric. 99:3635-3643. 
Ianni, A., D. Innosa, C. Martino, F. Bennato, and G. Martino. 2019b. Compositional characteristics and aromatic profile of caciotta cheese obtained from Friesian cows fed with a dietary supplementation of dried grape pomace. J. Dairy Sci. 102:1025-1032.

Imanishi, N., H. Kawai, Y. Hayashi, K. Yatsunami, and A. Ichikawa. 1989. Effects of glycyrrhizin and glycyrrhetinic acid on dexamethasone-induced changes in histamine synthesis of mouse mastocytoma $\mathrm{P}-815$ cells and in histamine release from rat peritoneal mast cells. Biochem. Pharmacol. 38:2521-2526.

Ju, H. S., X. J. Li, B. L. Zhao, Z. W. Han, and W. J. Xin. 1989. Effects of glycyrrhiza flavonoid on lipid peroxidation and active oxygen radicals. Yao Xue Xue Bao 24:807-812.

Kai, K., K. Komine, K. Asai, T. Kuroishi, Y. Komine, T. Kozutsumi, and K. Kumagai. 2003. Anti-inflammatory effects of intramammary infusions of glycyrrhizin in lactating cows with mastitis caused by coagulase-negative staphylococci. Am. J. Vet. Res. 64:1213-1220

Laemmli, U. K. 1970. Cleavage of structural proteins during the assembly of the head of bacteriophage T4. Nature 227:680-685.

Lawrence, R. C., L. K. Creamer, and J. Gilles. 1987. Texture development during cheese ripening. J. Dairy Sci. 70:1748-1760.

Lucey, J. A. J., and J. Kelly. 1994. Cheese yield. Int. J. Dairy Technol. 47:1-14.

McSweeney, P. L. H., P. F. Fox, and F. Ciocia. 2017. Metabolism of residual lactose and of lactate and citrate. Pages 411-423 in Cheese: Chemistry, Physics, and Microbiology. 4th ed. P. L. H. McSweeney, P. F. Fox, P. D. Cotter, and D. W. Everett, ed. Academic Press, San Diego, CA.

McSweeney, P. L. H., and M. J. Sousa. 2000. Biochemical pathways for the production of flavour compounds in cheeses during ripening: A review. Lait 80:293-324.

Morand-Fehr, P., V. Fedele, M. Decandia, and Y. Le Frileux. 2007. Influence of farming and feeding systems on composition and quality of goat and sheep milk. Small Rumin. Res. 68:20-34.

Nakamura, T., M. Kuriyama, E. Kosuge, K. Ishihara, and K. Ito. 1993. Effects of saiboku-to (TJ-96) on the production of plateletactivating factor in human neutrophils. Ann. N. Y. Acad. Sci. 685:572-579.

Ohtsuki, K., M. Oh-ishi, and N. Nagata. 1992. The stimulatory and inhibitory effects of glycyrrhizin and a glycyrrhetinic acid derivative on phosphorylation of lipocortin 1 by A-kinase in vitro. Biochem. Int. 28:1045-1053

Park, Y. W. 1992. Comparison of buffering components in goat and cow milk. Small Rumin. Res. 8:75-81.

Park, Y. W. 2001. Proteolysis and lipolysis of goat milk cheese. J. Dairy Sci. 84:84-92.

Park, Y. W., and G. F. W. Haenlein. 2007. Goat milk, its products and nutrition. Pages 447-486 in Handbook of Food Products Manufacturing. Y. H. Hui, ed. John Wiley and Sons, New York, NY.

Rasband, W. S. 2012. ImageJ software. National Institutes of Health, Bethesda, MD.

Raynal-Ljutovac, K., G. Lagriffoul, P. Paccard, I. Guillet, and Y. Chilliard. 2008. Composition of goat and sheep milk products: An update. Small Rumin. Res. 79:57-72.

Reynolds, C. K., D. L. Harmon, and M. J. Cecava. 1994. Absorption and delivery of nutrients for milk protein synthesis by portaldrained viscera. J. Dairy Sci. 77:2787-2808.

Salles, C., N. Sommerer, C. Septier, S. Issanchou, C. Chabanet, A. Garem, and J. L. Le Quere. 2002. Goat cheese flavor: Sensory evaluation of branched-chain fatty acids and small peptides. J. Food Sci. 67:835-841.

Sanz Sampelayo, M. R., Y. Chilliard, P. Schmidely, and J. Boza. 2007. Influence of type of diet on the fat constituents of goat and sheep milk. Small Rumin. Res. 68:42-67.
Sarantinopoulos, P., G. Kalantzopoulos, and E. Tsakalidou. 2002. Effect of Enterococcus faecium on microbiological, physicochemical and sensory characteristics of Greek Feta cheese. Int. J. Food Microbiol. 76:93-105.

Silanikove, N., G. Leither, U. Merin, and C. Prosser. 2010. Recent advances in exploiting goat's milk: Quality, safety and production aspects. Small Rumin. Res. 89:110-124.

Singh, T. K., M. A. Drake, and K. R. Cadwallader. 2003. Flavor of Cheddar cheese: A chemical and sensory perspective. Compr. Rev. Food Sci. Food Saf. 2:166-189.

Šlapkauskaitè, J., K. Žalnieraitè, A. Šlapkauskas, and D. Sekmokiene. 2018. The influence of aqueous extracts on curd-type cheese quality. Zem. Ukio Moksl. 25:91-101.

Somjen, D., S. Katzburg, J. Vaya, A. M. Kaye, D. Hendel, G. H. Posner, and S. Tamir. 2004. Estrogenic activity of glabridin and glabrene from licorice roots on human osteoblasts and prepubertal rat skeletal tissues. J. Steroid Biochem. Mol. Biol. 91:241-246.

Sousa, M. J., Y. Ardo, and P. L. H. McSweeney. 2001. Advances in the study of proteolysis during cheese ripening. Int. Dairy J. 11:327345 .

Szczechowiak, J., K. Szkudelska, M. Szumacher-Strabel, S. Sadkowski, K. Gwozdz, M. El-Sherbiny, M. Kozlowska, V. Rodriguez, and A. Cieslak. 2018. Blood hormones, metabolic parameters and fatty acid proportion in dairy cows fed condensed tannins and oils blend. Ann. Anim. Sci. 18:155-166.

Szczechowiak, J., M. Szumacher-Strabel, M. El-Sherbiny, E. PersKamczyc, P. Pawlak, and A. Cieslak. 2016. Rumen fermentation, methane concentration and fatty acid proportion in the rumen and milk of dairy cows fed condensed tannin and/or fish-soybean oils blend. Anim. Feed Sci. Technol. 216:93-107.

Thierry, A., and M. B. Maillard. 2002. Production of cheese flavour compounds derived from amino acid catabolism by Propionibacterium freudenreichii. Lait 82:17-32.

Tziboula-Clarke, A. 2003. Goat milk. Pages 1270-1279 in Encyclopedia of Dairy Sciences. H. Roginski, J. W. Fuquay, and P. F. Fox, ed. Academic Press, Cambridge, MA.

Van Soest, P. J., J. B. Robertson, and B. A. Lewis. 1991. Methods for dietary fiber, neutral detergent fiber, and nonstarch polysaccharides in relation to animal nutrition. J. Dairy Sci. 74:3583-3597.

Vaya, J., P. A. Belinky, and M. Aviram. 1997. Antioxidant constituents from licorice roots: Isolation, structure elucidation and antioxidative capacity toward LDL oxidation. Free Radic. Biol. Med. 23:302-313.

Waghorn, G. C., and W. C. McNabb. 2003. Consequences of plant phenolic compounds for productivity and health of ruminants. Proc. Nutr. Soc. 62:383-392.

Yokota, T., H. Nishio, Y. Kubota, and M. Mizoguchi. 1998. The inhibitory effect of glabridin from licorice extracts on melanogenesis and inflammation. Pigment Cell Res. 11:355-361.

Yunusova, S. G., V. T. Daniiov, M. S. Yunusov, Y. L. Murinov, E. M. Tsyrlina, and R. Straek. 1995. Lipids of Glycyrrhiza glabra roots. Chemistry of natural compounds and bioorganic chemistry. Russ. Chem. Bull. 44:359.

\section{ORCIDS}

Andrea Ianni ๑ https://orcid.org/0000-0003-3102-6804

Alessio Di Luca (ㄱ https://orcid.org/0000-0003-4988-6407

Giuseppe Martino 으 https://orcid.org/0000-0002-7878-9318 